Orijinal araştırma (Original article)

\title{
Comparison of different bioassay methods for determining insecticide resistance in European Grapevine Moth, Lobesia botrana (Denis \& Schiffermüller) (Lepidoptera: Tortricidae) ${ }^{1}$
}

\author{
Salkım güvesi (Lobesia botrana)'nde insektisit direncinin belirlenmesinde farklı \\ biyoassay yöntemlerin karşılaştırılması
}

\author{
Enver DURMUŞOĞLU² Ahmet HATIPOĞLU² \\ M.Oktay GÜRKAN ${ }^{3} \quad$ Graham MOORES ${ }^{4}$
}

\begin{abstract}
Summary
The European Grapevine Moth [Lobesia botrana (Denis \& Schiffermüller) (Lepidoptera: Tortricidae)] is a major pest in vineyards and insecticides are heavily used in its management. Currently, there is no IRAC approved bioassay method for $L$. botrana, so this study aimed to develop a suitable susceptibility test. For this purpose, 10 different populations were cultured from Manisa (Turkey) that province an important place in the world of viticulture. Diet-incorporation, topical application and diet covering methods selected as potential methods. Three different bioassay techniques (diet-incorporation, diet covering and topical application) were compared using indoxacarb, deltamethrin, spinosad and chlorpyrifos-ethyl on three different populations. Results revealed that the dietincorporation by mixing was the most appropriate method for testing insecticide resistance against the European Grapevine Moth.
\end{abstract}

Keywords: Bioassay, European grape moth, insecticide resistance, diet incorporation, diet covering, topical application

\section{Özet}

Salkım güvesi [Lobesia botrana (Denis \& Schiffermüller) (Lepidoptera: Tortricidae)] bağın ana zararlısıdır, salkım güvesi mücadelesinde yoğun olarak insektisit kullanılmaktadır. İnsektisit Direnç Eylem Komitesi (IRAC)'nde Lobesia botrana için onaylanmış bir yöntem olmadığından bu çalışma salkım güvesinde hassasiyet test metodu geliştirmek amacıyla gerçekleştirilmiştir. Bu amaçla, dünya bağcılığında önemli bir yeri olan Manisa (Türkiye) ilinden 10 farklı populasyon kültüre alınmıştır. İnsektisiti besine karıştırma, topikal uygulama ve besin kaplama yöntemleri kullanılması muhtemel metotlar olarak seçilmiştir. Indoxacarb, Deltamethin, Spinosad ve Chlorpyrifos ethyl aktif maddeleri, 3 farklı populasyonda 3 farklı yöntem karşılaştırmalı olarak kullanılmıştır. Sonuçlar, salkım güvesinde hassasiyet test metodu olarak insektisitin besine karıştırma yönteminin en uygun metod olduğunu göstermiştir.

Anahtar sözcükler: Biyoassay, Salkım güvesi, insektisit direnci, besine karıştırma, besin kaplama, topikal uygulama

\footnotetext{
${ }^{1}$ This study was supported by TUBITAK-TOVAG (Project No: 1100637) and EBILTEM (Project No: 2011-BIL-031), and it is a part of the second author's Ph.D. thesis.

${ }^{2}$ Ege University, Agricultural Faculty, Plant Protection Department, Izmir, Turkey

${ }^{3}$ Ankara İleri Teknoloji Yatırımları A.Ş., Ankara Teknoloji Geliştirme Bölgesi, Ankara, Turkey

${ }^{4}$ Apres Labs Ltd Harpenden, United Kingdom

* Sorumlu yazar (Corresponding author) e-mail: ahmet.hatipoglu@ege.edu.tr

Alınış (Received): 23.07.2015 Kabul ediliş (Accepted): 06.10.2015 Çevrimiçi Yayın Tarihi (Published Online): 21.10.2015
} 


\section{Introduction}

Chemical insecticides are still considered the mainstay of agricultural pest control. Although development of resistance against insecticides is a common phenomenon, recent advances in research and technology has renewed interest in this subject and resistance risk assessments have been developed for many species using different assay methods.

In 1984 the Insecticide Resistance Action Committee (IRAC) was established for improved and systematic reporting of insecticide resistance. According to IRAC, resistance is a decrease of a pest population's susceptibility as the result of genetic changes, such that an insecticide is no longer effective when used at the prescribed dose. Short life span and high fecundity are among major factors that contribute to the onset of resistance to insecticides, when they are used extensively. The development of insecticide resistance is one of the most important problems in pest management, affecting agricultural production with an ultimate impact on yield. About 600 insect and mite species are reported to have developed resistance against insecticides (IRAC, 2014).

Reliable, quick and effective bioassay techniques to identify sensitive and resistant individuals are needed for effective resistance management (Brown, 1981; Gunning, 1993). One of the most important reasons to conduct resistance studies is to suggest more effective and safer insecticides to delay resistance development (Roush \& Tabashnik, 1990).

Accuracy and a clear definition of the method of reporting insecticide resistance studies are critically important for comparison with results from other studies. IRAC has published 188 methods to determine the resistance of insects against insecticides (IRAC, 2014). The European Grapevine Moth (EGM) is multivoltine and an important pest in vineyards of Turkey and throughout Europe; as such, it is heavily sprayed during the year (Delen et al., 2004). However, the scarce literature on this pest is a major obstacle to finding a reliable and accurate method to manage resistance risk development in EGM.

There are several standard bioassay methods to determine insecticide resistance for important pest species; these methods are classified according to the technique of insecticide application (FfrenchConstant \& Roush, 1990). The methods can be grouped into four headings; dipping, residue (diet covering), topical application and feeding. The aim of the present study was to compare the last three methods; residue, topical application and feeding bioassays to select the best methods for monitoring insecticide resistance on the EGM. The outcome of this study would be useful for further studies with EGM.

\section{Materials and Methods}

Insects

The resistance related bioassay studies were conducted in the Entomology Laboratory, Department of Plant Protection, Faculty of Agriculture, Ege University, Turkey. EGM was collected from three different locations (Merkez 1, Merkez 2 and Yesilyurt region) in Manisa, Turkey. The insect colony was maintained at $25 \pm 2^{\circ} \mathrm{C}, 60-65 \% \mathrm{RH}$ in the laboratory with a $16: 8 \mathrm{~h}$ light: dark photoperiod.

\section{Insecticides}

Insecticides used as active ingredients (\%96-99 purity) in the bioassay were: chlorpyrifos-ethyl (Dow AgroSciences, Turkey), deltamethrin (Bayer Crop Science, Turkey), Indoxacarb (Hektaş, Turkey) and spinosad (Dow AgroSciences, Turkey).

\section{Diet preparation}

The diet was prepared as described in Rapagnani et al. (1990). According to this method, two autoclavable, screw capped 1 I glass bottles were used in diet preparation. The agar $(20 \mathrm{~g})$ and corn semolina $(64 \mathrm{~g}$ ) were added to one of these bottles with $500 \mathrm{ml}$ pure water. Later, these two bottles (other bottle including only $500 \mathrm{ml}$ pure water) were sterilized at $120^{\circ} \mathrm{C}$ for 20 minutes in an autoclave. After that the diet media and other pure water were poured in a mixer at $70^{\circ} \mathrm{C}$. Other bottle of pure water was used 
for the easier removal of the diet media. Wheat germ $(66 \mathrm{~g})$ and brewer's yeast $(30 \mathrm{~g})$ were added and mixed properly. When the mixture temperature dropped to $60^{\circ} \mathrm{C}$, ascorbic acid $(5.7 \mathrm{~g}$ was solved in $2 \mathrm{ml}$ pure water and nipagin was solved in \% 96 alcohol (very little amount $\sim 1 \mathrm{ml}$ ) and then they were added into the mixture. After mixing all the ingredients, the resulting $1 \mathrm{lt}$ of artificial diet was placed in sterile plastic containers, and covered with aluminium foil, and left at room temperature for 24 hours. When the diet properly settle down, it was chopped into $1 \mathrm{~cm}^{3}(\sim 1.3 \mathrm{~g})$ cubes. The pure diet cubes were placed in a sixteen cell transparent containers and used for experiments of Topical bioassay \& Diet covering methods (Bio-Assay Tray Lid - 16 cells, Bio-Serv Canada) (Fig.1). For diet incorporation method, diet cubes mixed with insecticide were used.

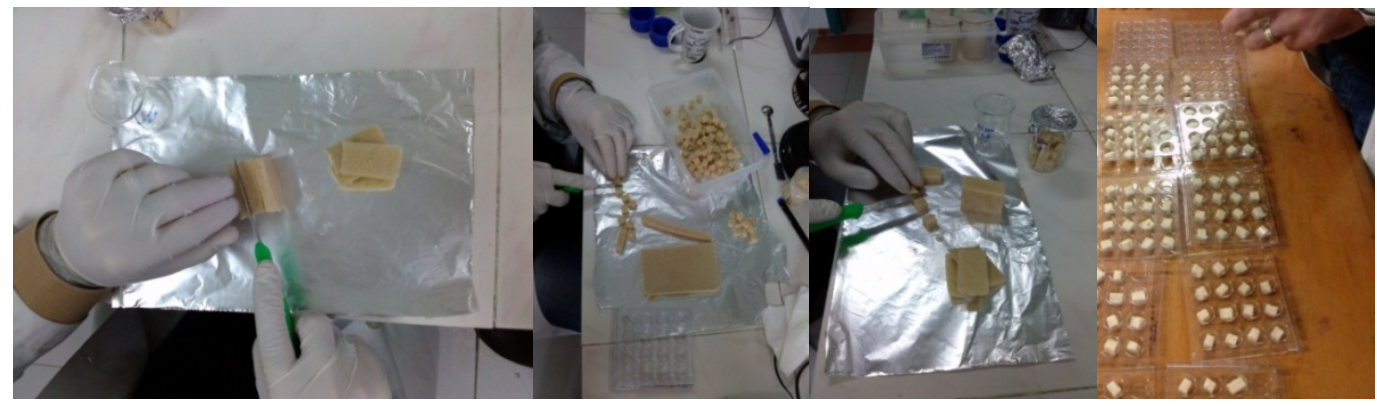

Figure 1. Dividing the diet which has been placed in storage boxes into $1 \mathrm{~cm}^{3}$ pieces and placing them on experiment containers.

\section{Bioassays}

\section{Topical bioassay}

A hand-operated micro-applicator (Burkard, England) was used to apply aliquots $(1 \mu \mathrm{L})$ on the thorax of individual $3^{\text {rd }}$ stage larvae previously placed at $4^{\circ} \mathrm{C}$ for 4 minutes. They were then transferred into a 16-well polystyrene bioassay tray (Bio-Serve, Canada). Each cell contained a larva: The process was repeated for 30 individuals for each dose, with distilled water as the control. The bioassay tray was covered and incubated at $25 \pm 2^{\circ} \mathrm{C}, 60-65 \% \mathrm{RH}$ with a $16: 8 \mathrm{~h}$ light: dark photoperiod. Mortality was assessed after 72 hours, and larvae were considered dead if unresponsive to gentle prodding with a fine brush. The observations were made and could not be observed pupae of these larvae. If moribund insect cannot be pupae, it was assessed as dead.

\section{Diet covering}

Two $\mathrm{ml}$ of insecticide were applied to a petri dish containing 10 cubes of diet using a Potter-Tower (Burkard, England) at a pressure of 1 bar. Two $\mathrm{ml}$ of sterile distilled water was used as a control. Each treatment was repeated three times. To be contacted with insecticide of the bottom surface of the diet cubes, diet cubes were transferred help of forceps sprayed surface of the petri dish immediately after application. The diet cubes were kept for 30 minutes at room temperature then transferred to individual cells of the 16 -well polystyrene bioassay tray. A single $3^{\text {rd }}$ stage larvae was placed into each cell and the tray covered and maintained at $25 \pm 2^{\circ} \mathrm{C}, 60-65 \% \mathrm{RH}$ with a 16:8 h light: dark photoperiod for 72 hours after which mortality was assessed as before.

\section{Diet incorporation}

Concentrations of insecticide were mixed with the prepared diet at a ratio of 1: 9 after waiting for the temperature of artificial diet to drop to $40{ }^{\circ} \mathrm{C}$ (the lowest temperature insecticides not lost integrity). The mixture was homogenised, left for $24 \mathrm{hrs}$ at room temperature and then cut into $1 \mathrm{~cm}^{3}$ pieces. Diet was mixed with sterile distilled water as a control. The cubes were placed into individual cells of the 16well polystyrene bioassay tray. A single $3^{\text {rd }}$ stage larvae was placed into each cell and the tray covered and kept at $25 \pm 2^{\circ} \mathrm{C}, 60-65 \% \mathrm{RH}$ with a 16:8 h light: dark photoperiod for 72 hours after which mortality was assessed as described above.

All three methods were repeated once a month intervals in the same way in three different dates. 


\section{Statistical analysis}

The lethal concentration (LC) values were calculated by probit analysis using Polo Plus software version 2.0 (Le Ora Software, Berkeley, CA)."Natural response parameter" and "Convert doses to logarithms" options "yes" was selected.

\section{Results and Discussion}

The aim of our study was to determine the most suitable bioassay method for resistance risk assessment of EGM. The methods of topical application, diet covering, and diet incorporation methods were applied with a series of insecticide concentration with many pre-experiments. Three different EGM populations were used in the experiments. Factors like amount of the diet, application time, temperature, and humidity were kept constant throughout the experiments.

The topical application method was difficult due to small size and continuous movement of larvae. To overcome these difficulties, preliminary experiments were carried out to determine the incubation time of the larvae in the fridge to make them immobile. The larvae were placed in sterilized plastic petri dishes in groups of 10 and were kept for four minutes in the freezer $\left(0^{\circ} \mathrm{C}\right)$. It was observed that larvae kept in the fridge for 4 minutes became mobile after spending 1 minute in room temperature. That one minute time length was enough to do topical application to 10 larvae. The topical application was carried out after placing the larvae for 4 minutes in the freezer. Also, even if a drop of the solution is given without a problem, we observed another problem where the larvae became mobile before absorbing the liquid completely and transmitted the liquid to the area.

Before starting the experiments, as a preliminary experiment, water and methanol were applied to the larvae in order to analyse the side effects of methanol, used in dissolving the active ingredients. One $\mu \mathrm{l}$ methanol or water was applied to each larva. Water was used in 3 petri dishes containing 5 larvae each. Simultaneously methanol was applied to 15 larvae. Later, these larvae were left with diet and observed until turning into pupae. There was no difference observed between the applications of methanol and distilled water. In the topical application the active ingredient directly applied to the insect's body. Thus, using low doses in this method appeared to be successful.

After the preliminary experiments in the diet covering method, it was observed that the dose required complete death was quite high. Obtaining a homogeneous mixture and blockage of spray tower were observed as technical problems during application the insecticides. The dose series with effective results in this method was very high comparing with other methods. The method of diet incorporation was the only method in that the increase of death ratio was observed with increasing doses.

Although the same insecticides and the same insect were used the tested methods produced varying results depending on the application methods. The physical environments needed for a successful execution of the methods are different. For example, there was a need of good ventilation while using the spray tower. It was compulsory to place larvae in low temperature for the topical application. However, a specific temperature was required in mixing the insecticide with diet. While two methods other than the mixing method are immediately applicable after preparing insecticide solution, a period of time is required to expose the insects to insecticides.

There was a significant difference between the doses that produce $100 \%$ mortality. Therefore, it was necessary to determine a different series concentration for each method. In the mixing method, $100 \%$ mortality was observed at the maximum dose in all the insecticides and this method appeared to be more reliable than others. In the diet covering method, a higher concentration of insecticides was used to ensure covering all surface area the diet, which enable to deliver enough dose to produce mortality.

Results of the three bioassay methods are presented in Table 1 . The $\mathrm{LC}_{50}$ values obtained in the diet incorporation method appeared to be more precise than for the other methods, i.e. the $95 \%$ confidence intervals $(\mathrm{Cl})$ were smaller. Heterogeneity values of the three methods for the different populations are also presented in Table 1. These values were $0.2-4.6$ for the incorporation method, 0.7 -10.4 for the covering method and $0.9-10.8$ for the topical application method. Based on these values, the diet incorporation method delivered the results that can be interpreted by probit analysis. 
Table 1. Results from three different bioassay methods on EGM populations

\begin{tabular}{|c|c|c|c|c|c|c|c|}
\hline $\mathrm{Al}$ & $M$ & $P$ & $\mathrm{~N}^{*}$ & LC50 (ppm) & LC90 (ppm) & $\mathrm{H}$ & Slope \pm SE \\
\hline \multirow{9}{*}{ 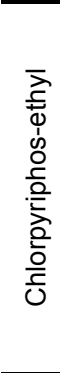 } & \multirow{3}{*}{$\begin{array}{c}\text { Diet } \\
\text { incorporation }\end{array}$} & Merkez 1 & \multirow{3}{*}{450} & $\underline{4,47(1,94-9,04)}$ & $38,42(17,41-158,28)$ & 2,56 & $1,37 \pm 0,10$ \\
\hline & & Yeşilyurt & & $16,44(12,96-20,63)$ & $102,80(73,69-160,65)$ & 0,24 & $1,61 \pm 0,14$ \\
\hline & & Merkez 2 & & $4,09(3,16-5,19)$ & $21,69(16,32-30,81)$ & 0,42 & $1,76 \pm 0,14$ \\
\hline & \multirow{3}{*}{ Diet covering } & Merkez 1 & \multirow{3}{*}{540} & $658,26(164,22-9447,60)$ & $104988,11(7962,15-938369909,32)$ & 4,41 & $0,58 \pm 0,05$ \\
\hline & & Yeşilyurt & & $82,69(13,12-361,08)$ & $1370,74(323,79-112270,25)$ & 9,68 & $1,051 \pm 0,07$ \\
\hline & & Merkez 2 & & $411,51(119,78-2352,09)$ & $17088,81(2784,26-5429528,21)$ & 5,36 & $0,79 \pm 0,06$ \\
\hline & \multirow{3}{*}{$\begin{array}{l}\text { Topical } \\
\text { application }\end{array}$} & Merkez 1 & \multirow{3}{*}{540} & $19,36(2,24-84,14)$ & $300,92(72,57-66609,92)$ & 10,74 & $1,07 \pm 0,08$ \\
\hline & & Yeşilyurt & & $51,39(10,76-248,76)$ & $873,21(197,85-233486,85)$ & 9,43 & $1,04 \pm 0,07$ \\
\hline & & Merkez 2 & & $46,51(12,23-167,69)$ & $1083,63(259,23-82236,44)$ & 6,56 & $0,93 \pm 0,07$ \\
\hline \multirow{9}{*}{$\begin{array}{l}\text { D } \\
\text { D } \\
\stackrel{0}{\bar{C}} \\
\text { के }\end{array}$} & \multirow{3}{*}{$\begin{array}{c}\text { Diet } \\
\text { incorporation }\end{array}$} & Merkez 1 & \multirow{3}{*}{630} & $0,66(0,34-1,16)$ & $3,72(1,96-12,38)$ & 4,43 & $1,71 \pm 0,12$ \\
\hline & & Yeşilyurt & & $0,85(0,62-1,11)$ & $3,92(2,83-6,18)$ & 1,02 & $1,94 \pm 0,17$ \\
\hline & & Merkez 2 & & $1,00(0,83-1,19)$ & $4,11(3,23-5,56)$ & 0,23 & $2,08 \pm 0,15$ \\
\hline & \multirow{3}{*}{ Diet covering } & Merkez 1 & \multirow{3}{*}{540} & $114,11(27,44-264,41)$ & $1191,39(474,55-11304,61)$ & 4,61 & $1,25 \pm 0,11$ \\
\hline & & Yeşilyurt & & $36,23(27,10-47,51)$ & $328,11(235,73-488,74)$ & 0,73 & $1,339 \pm 0,09$ \\
\hline & & Merkez 2 & & $39,88(10,25-115,08)$ & $656,15(207,08-7248,94)$ & 5,83 & $1,05 \pm 0,07$ \\
\hline & \multirow{3}{*}{$\begin{array}{l}\text { Topical } \\
\text { application }\end{array}$} & Merkez 1 & \multirow{3}{*}{540} & $10,69(2,15-29,80)$ & $295,26(61,80-3446,68)$ & 5,88 & $1,01 \pm 0,08$ \\
\hline & & Yeşilyurt & & $25,40(8,62-61,97)$ & $270,24(100,16-2657,07)$ & 5,81 & $1,24 \pm 0,09$ \\
\hline & & Merkez 2 & & $19,81(11,17-32,41)$ & $144,63(79,66-386,22)$ & 2,37 & $1,48 \pm 0,11$ \\
\hline \multirow{9}{*}{ 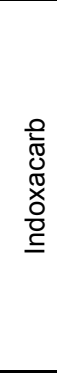 } & \multirow{3}{*}{$\begin{array}{c}\text { Diet } \\
\text { incorporation }\end{array}$} & Merkez 1 & \multirow{3}{*}{630} & $1,86(0,93-3,33)$ & $12,78(6,53-43,39)$ & 4,19 & $1,53 \pm 0,11$ \\
\hline & & Yeşilyurt & & $2,19(0,85-4,31)$ & $19,34(8,93-89,96)$ & 4,58 & $1,35 \pm 0,10$ \\
\hline & & Merkez 2 & & $2,98(2,25-3,81)$ & $22,76(16,80-33,60)$ & 0,59 & $1,45 \pm 0,12$ \\
\hline & \multirow{3}{*}{ Diet covering } & Merkez 1 & \multirow{3}{*}{540} & $228,50(43,92-939,79)$ & $2485,00(683,03-449106,97)$ & 9,48 & $1,236 \pm 0,09$ \\
\hline & & Yeşilyurt & & $27,12(3,80-105,83)$ & $813,69(186,54-34870,12)$ & 7,24 & $0,86 \pm 0,06$ \\
\hline & & Merkez 2 & & $65,38(7,90-321,21)$ & $2930,02(515,14-894322,89)$ & 7,78 & $0,77 \pm 0,06$ \\
\hline & \multirow{3}{*}{$\begin{array}{l}\text { Topical } \\
\text { application }\end{array}$} & Merkez 1 & \multirow{3}{*}{540} & $5,66(0,79-15,26)$ & $77,69(28,06-745,85)$ & 4,79 & $1,12 \pm 0,10$ \\
\hline & & Yeşilyurt & & $12,05(3,82-25,09)$ & $92,23(42,19-454,65)$ & 4,31 & $1,45 \pm 0,12$ \\
\hline & & Merkez 2 & & $83,12(38,88-191,75)$ & $3171,67(914,81-41855,01)$ & 2,39 & $0,81 \pm 0,07$ \\
\hline \multirow{9}{*}{ 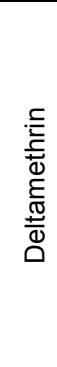 } & \multirow{3}{*}{$\begin{array}{c}\text { Diet } \\
\text { incorporation }\end{array}$} & Merkez 1 & \multirow{3}{*}{450} & $3,73(2,61-5,04)$ & $29,67(21,21-45,61)$ & 0,97 & $1,420,13$ \\
\hline & & Yeşilyurt & & $7,93(5,62-11,14)$ & $191,20(110,99-392,24)$ & 0,48 & $0,92 \pm 0,07$ \\
\hline & & Merkez 2 & & $6,03(3,41-10,27)$ & $88,70(43,79-263,90)$ & 1,16 & $1,09 \pm 0,08$ \\
\hline & \multirow{3}{*}{ Diet covering } & Merkez 1 & \multirow{3}{*}{540} & $57,14(22,54-126,37)$ & $1494,53(553,52-8434,74)$ & 2,90 & $0,9 \pm 0,06$ \\
\hline & & Yeşilyurt & & $101,74(18,01-335,20)$ & $615,50(211,51-24278,71)$ & 10,35 & $1,63 \pm 0,12$ \\
\hline & & Merkez 2 & & $240,92(74,57-738,83)$ & $2878,73(886,23-86752,22)$ & 6,52 & $1,19 \pm 0,09$ \\
\hline & \multirow{3}{*}{$\begin{array}{l}\text { Topical } \\
\text { application }\end{array}$} & Merkez 1 & & $11,46(6,27-18,69)$ & $2254,60(965,02-7890,68)$ & 0,92 & $0,55 \pm 0,06$ \\
\hline & & Yeşilyurt & 540 & $6,12(0,44-21,83)$ & $86,79(23,95-6195,33)$ & 9,04 & $1,11 \pm 0,08$ \\
\hline & & Merkez 2 & & $54,72(31,18-96,14)$ & $2688,90(1030,03-12902,14)$ & 1,18 & $0,75 \pm 0,06$ \\
\hline
\end{tabular}

$\mathrm{Al}=$ Active Ingredient, $\mathrm{M}=$ Method, $\mathrm{P}=$ Population, $\mathrm{N}=$ Number of larvae, $\mathrm{H}=$ Heterogeneity

$\mathrm{LC}_{50}=$ Concentration that confers 50\% mortality (95\% Confidence Intervals); $\mathrm{LC}_{90}=$ Concentration that confers $90 \%$ mortality $(95 \%$ Confidence Intervals).

${ }^{*}$ Each population were tested with three different insecticides in 3 different dates with 30 insects per 6 (or $5 \& 7$ ) doses. Therefore, the number 540 (or 450\&630) appeared individuals.

The Merkez 1 population had not been exposed to any insecticides for many years so that it was considered to be a susceptible population. The $\mathrm{LC}_{50} / \mathrm{LC}_{90}$ values for this population were expected to be lower than for the other populations. The $L_{5}$ values obtained from the incorporation method for all insecticides were lower or equivalent to those of the other methods. In the other methods the lowest $\mathrm{LC}_{50}$ values were observed in different populations. For example, in the diet covering method the $\mathrm{LC}_{50}$ values for three insecticides in the Merkez 1 population were very high as opposed to expectations. In the topical application method, the lowest $\mathrm{LC}_{50}$ value for deltamethrin was found in the Yesilyurt population.

An increase in mortality should be directly proportional to increase in dosage of insecticide and this serves as another means of comparing methods. The 'slope' values that reflect this relationship are 
presented in Table 1. These values were between 0.92 and 2.08 in the incorporation method as 0.58 to 1.63 in the diet covering method and 0.55 to 1.48 in the topical application method. The diet incorporation method seems to be the best method for comparison the dose-mortality relationship.

From the literature there are a limited number of studies on insecticide resistance and suitable bioassay methods with EGM. In the current study, testing four different insecticides against ten EGM populations from Manisa vineyards using diet incorporation showed that Ahmetli and Alasehir populations were potentially resistant to indoxacarb (Hatipoglu et al., 2015). A high resistance was also detected in Italy using the same bioassay method (Civolani et al., 2014). Perez et al. (1997) compared the leafdipping and diet incorporation methods to determine resistance of diamond back moth (Plutella xylostella) against Bacillus thuringiensis. The researchers stated that "if one wants to choose a concentration which kills $99 \%$ of a susceptible population the leaf-dipping bioassay method is a more efficient method to distinguish between resistant and susceptible individuals; because this method kills the more resistant individuals in a lower ratio compared to the bioassay using artificial diet." However, fFrench-Constant and Roush (1990) pointed out that an ideal bioassay method should be quick and efficient, thus insecticide incorporated into artificial diet would be the bioassay of choice where possible.

The major focus of this study was to test the suitability of various bioassay methods for measuring resistance of EGM against insecticides. The results confirmed that the diet incorporation method was the more suitable bioassay method in resistance studies against EGM.

\section{Acknowledgements}

The authors would like to thank TUBITAK for supporting this study under the project TOVAG 110637, to EBILTEM for supporting this study under the project 2011-BIL-031 and for Agrobest Group, Bayer Crop Science Turkey, Dow AgroScience Turkey and Hektaş, for supplying insecticides used in this study.

\section{References}

Brown, T.M., 1981, Counter measures for insecticide resistance. Bulletin of the Entomological Society of America, 27:198-202.

Civolani, S., M. Boselli, A. Butturini, M. Chicca, E.A. Fano \& S. Cassanelli, 2014. Assessment of insecticide resistance of Lobesia botrana (Lepidoptera: Tortricidae) in Emilia-Romagna Region. Journal of Economic Entomology, 107:12451249.

Delen, N., C. Koplay, M. Yıldız, N. Güngör, P. Kınay, F. Yıldız \& A. Coşkuntuna, 2004. Sensivity in Botyrtis cinerea isolates to some fungicides with specific mode of action. XIII. Botyrtis Symposium (25-31 October 2004, Antalya), Abstracts, 131p.

Ffrench-Constant, R.H. \& R.T. Roush, 1990. "Resistance Detection and Documentation: The Relative Roles of Pesticidal and Biochemical Assays, 4-38". In: Pesticide Resistance in Arthropods (Eds: R.T. Roush \& B.E. Tabashnik), Chapman and Hall, New York.

Gunning, R.V., 1993. Comparison of the two bio-assay techniques for larvae of Helicoverpa sp. (Lepidoptera: Noctuidae). Journal of Economic Entomology, 86: 234-238.

Hatipoglu A., E. Durmuşoğlu \& M.O. Gürkan, 2015. Manisa ili bağ alanlarında Salkım güvesi [Lobesia botrana (Denis \& Schiffermüller) (Lepidoptera: Tortricidae)] popülasyonlarının insektisit direncinin belirlenmesi, Turkish Journal of Entomology, 39 (1): 55-65.

IRAC, 2014. Resistance Definition, Backround, Development. (Web page:http://www.irac-online.org/about/resistance) (Date accessed: Feb 2014).

Perez, C.J., J.D. Tang \& A.M. Shelton, 1997. Comparison of leaf-dip and diet bioassays for monitoring Bacillus thuringiensis resistance in field populations of diamondback moth (Lepidoptera: Plutellidae), insecticide resistance and resistance management. Journal of Economic Entomology, 90: 94-101.

Rapagnani, M. R., V. Cafferelli, M. Barlettoni \& F. Mineli, 1990. Descrizione di un alleuamento in labratorio, dele tignolotta dell'ura Lobesia botrana Den.-Schiff. (Lepidoptera: Tortricidae) su on nuova alimento semi-sintetica, Bolletino dell Istituto di Entomologia 'Guido Grandi' dell Universito di Bologna, XLIV: 57-64.

Roush, R.T. \& B.E. Tabashnik, 1990. Pesticide Resistance in Arthropods. Chapman and Hall, New York and London, 303p. 